\title{
EVOLUTION OF RELATIONSHIP BETWEEN HOUSING AND RENTAL PRICES AND INTER- URBAN DIFFERENCES IN CHINA UNDER THE CONTEXT OF THE SIMULTANEOUS RENTAL AND SALES MARKETS POLICY
}

\section{Guancen $\mathbf{W u}$}

School of Management

Shanghai University, Shanghai, China

e-mail:wuguancen@shu.edu.cn

\section{Xing Niu}

School of Social and Public Administration

East China University of Science

Technology, Shanghai, China

e-mail: niuxing@ecust.edu.cn

\section{Li Tao}

School of Management

Shanghai University, Shanghai, China

e-mail:taoli@i.shu.edu.cn

\author{
Chen Li \\ School of Management \\ Shanghai University, Shanghai, China \\ e-mail:1746862058@qq.com

\section{Ping Li} \\ School of Management \\ and Shanghai University, Shanghai, China \\ e-mail: 1293989458@qq.com
}

\begin{abstract}
This research analyzes the relationship between housing and rental prices in 26 first-tier and secondtier cities in China before and after the policy of simultaneous rental and sales markets. The PVAR model and monthly panel data of these cities from June 2010 to December 2018 were employed. The study found that, before the policy of simultaneous rental and sales markets took effect, the housing and rental prices were relatively independent of each other, whereas the rental market in second-tier cities is affected more considerably by the sales market. After the enactment of the policy on simultaneous rental and sales markets, rental prices have a positive effect on housing prices, with this effect being more obvious in second-tier cities. The rental prices with the first-order lag have a significant negative impact on current rental price in first-tier cities. Considering the features of the housing market in different cities, the implementation of the simultaneous rental and sales markets policy needs to be more targeted and attention should be paid to preventing simultaneous irrational growth, both on the sales and rental markets.
\end{abstract}

Key words: housing price; rental price; PVAR model.

JEL Classification: R30, R31.

Citation: Wu, G., Li, C., Niu, X., Li, P., \& Tao, L. (2021). Evolution of relationship between housing and rental prices and inter-urban differences in china under the context of simultaneous rental and sales markets policy. Real Estate Management and Valuation, 29(3), 29-38.

DOI: https://doi.org/10.2478/remav-2021-0019

\section{Introduction}

From the perspective of housing consumption, the real estate market includes not only the sales 
market but also the rental market (Tomal, 2020). As major factors in the two markets, housing and rental prices interact with each other to some extent. Rent, as a return on investment in housing, will push housing prices up, and the increase in housing prices will also drive up rents accordingly. In different urban circumstances, the substitution effect between the rental market and sales market, speculative behavior of the real estate market, preferences of residents for a house of their own and changes in the supply and demand of the housing market will lead to a complex interrelationship between housing prices and rent, as well as rents and housing prices themselves. More importantly, regulatory measures may also change the relationship between sales and rental markets by influencing the supply and demand of housing for sale and housing for $\operatorname{rent}(\mathrm{Tu}, 2018)$. As a consequence, relationships between housing and rental prices will also have regional heterogeneity because of the differences in housing market development, housing policies and cultural backgrounds (Lisa, 2019).

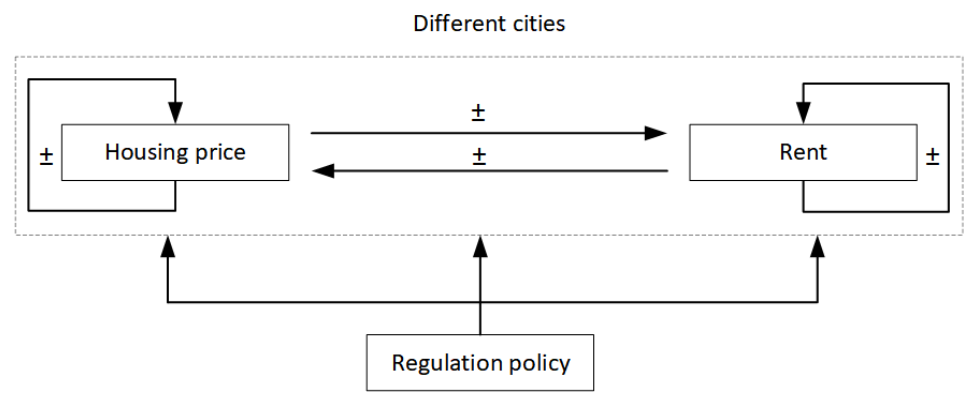

Fig. 1. Relationship between housing price and rent. Source: own study.

For a long time, the phenomenon of "sale emphasis and rent ignorance" has been prevalent in China, resulting in a generally low proportion of the housing rental market (Cui et al., 2018). The rental and sales markets are in a relatively fragmented status causing a deviation in housing and rental prices (Zhai et al., 2018). The relationship between the two markets is not close enough. In recent years, however, the Chinese government has gradually given attention to this imbalance in the housing sales and rental market, and begun to control housing prices through credit, financial and administrative tools. The Chinese government has continuously been issueing various policies to encourage the development of the rental market. In 2017, the Ministry of Housing and Urban-Rural Development and nine other ministries and commissions jointly issued the "Notice on Accelerating the Development of the Rental Housing Market in Large and Medium Cities with a Net Inflow of Population". Many cities have also begun to actively put these policies into practice. They attempt to create an effective connection between the rental and sales markets through the development of the rental market and promote the stable and healthy development of the real estate market.

This paper aims to investigate whether more linkages and interactions are formed for the rental and the sales markets in first-tier and second-tier cities, and whether the relationship between housing and rental prices is different in different cities. In-depth analysis of such problems can provide references for the policymakers, the strategic formulation of enterprises in real estate, and the consumers' choice of residence.

\section{Literature review}

Theoretically, it can be seen that the housing and rental prices should have a relatively balanced relationship. In 1992, the "four-quadrant model" was constructed by DiPasquale and Wheaton to describe the relationship between the sales market and the rental market (Dipasquale et al., 1992). The four-quadrant model is a good explanation that housing prices are restricted by rent and affects the housing increment at the same time, which, in turn, affects the housing stockand, finally, the rent. In 1996, Clayton (1996) proposed that the relationship between rental and housing prices is similar to the relationship between stock dividends and stock prices in the stock market. Empirical studies of Meese and Wallace (1994) and Gallin (2008) both showed that housing and rental prices are co-integrated.

However, some scholars believe housing and rental prices are uniaxially influenced by each other, which is mainly that housing price changes affect rental price, while rental price changes have a limited influence on the changes in housing price. Du and Ma (2009) found that housing prices and rental price are independent of each other in the short term in all of China, but that housing prices are a long-term cause of changes in rent. Manganelli (2014) investigated the relationship between housing 
and rental prices on the Italian housing market. The results show that housing prices can affect rental price but rental price does not affect housing prices. Li Ning (2014) found that housing prices can affect rental price in both short-term and long-term periods, but the impact of rent on housing prices is small.

The relationships between rent and housing prices also varied from city to city (Potepan, 1996). This is affected by certain factors, such as supply restraint regulations and contracts in the housing market. With the dynamic Gordon model and annual data of 23 cities in the United States from 1975 to 2007, Campbell et al. (2009) indicated that the housing price expectation is one of the most important factors of the rent-price ratio. Research results of Chinese scholar Zhou (2005) indicated that housing and rental prices have a no co-integration relationship, which verifies the lack of a rentbuying mechanism in China's housing market. Du and Ma (2009) found that the relationship between housing prices and rental price is also different in Beijing, Shanghai, Hangzhou, and Shenzhen. Zhang (2014) found that the relationship between housing prices and rental price will be different due to different types of cities in China. Czerniak and Rubaszek(2018) found that a developed rental market attenuates fluctuations in the housing sector. Chen (2020) concluded that causal relationships between housing rents and housing prices in Beijing Shanghai, Shenzhen and Guangzhou are different and volatile.

Since the PVAR model can measure the interdependence between endogenous variables, it has been widely used in economic research. Magazzino (2017) constructed a 3-variable PVAR model and used the panel data of 19 APEC countries to empirically analyze the relationship among CO2 emissions, energy consumption and economic growth. The relationship between financial stress, inflation and growth in 19 advanced economies over the period 1999-2016 was studied by Apostolakis (2019). The panel data of 30 Chinese provinces, from the first quarter of 1996 to the first quarter of 2015, were taken as samples to study the endogenous relationship between China's financial development, energy consumption and economic growth (Ouyang et al., 2018). Some scholars also used the PVAR model to analyze the relationship between housing prices and the macro economy (Adams et al., 2010; Zhang, 2016).

In general, studies on the relationship between housing prices and rental prices are abundant, and different research conclusions can be drawn from various research data for different periods and cities. Some scholars have also noticed the heterogeneity of the relationship between housing prices and rental prices in cities. But changes in the relationship between the sales and rental markets during different periods of housing market regulation were overlooked. This paper analyzes the relationship between housing and rental prices in first-tier and second-tier cities in China, and compares the changes in the relationship before and after the policy of simultaneous rental and sales markets in first-tier and second-tier cities. This paper employs monthly data of stocking housing price and rental price, which is more helpful for the purposes of research than annual statistical data. The PVAR model, which can be used to measure the mutual influence between the housing price and rental price in different periods and cities, is adopted in this paper.

\section{Data and Methodology}

\subsection{Data illustration}

As the research focuses mainly on a more mature housing market, 26 large and medium-sized cities with more developed economies, sustained population growth and strong demand for the housing market were selected for analysis. These cities are located in eastern coastal zones, important economic zones of the central and western regions. These cities also include first-tier and second-tier cities in the national residential sales price statistics of the National Bureau of Statistics.

The sample city data include monthly housing prices (p) and rental prices (r) from June 2010 to December 2018, which are derived from the WIND database. The Wind database includes various financial market data and China's macro-industry, especially monthly housing price and rental price data, which cannot be provided in the National Statistical Yearbook. The unit of housing price is RMB yuan per square meter of floor space, and the rental price unit is RMB yuan per square meter per month in WIND database. The analysis software is STATA. 
Sample city type

\begin{tabular}{ll}
\hline First-tier cities & Beijing, Shanghai, Guangzhou, Shenzhen \\
\hline Second-tier cities & $\begin{array}{l}\text { Tianjin, Chongqing, Changchun, Chengdu, Changsha, Dalian, Fuzhou, } \\
\text { Guiyang, Harbin, Hefei, Hohhot, Haikou, Hangzhou, Jinan, Kunming, } \\
\text { Lanzhou, Ningbo, Nanchang, Nanjing, Nanning, Qingdao, Shijiazhuang, } \\
\text { etc. }\end{array}$ \\
\hline
\end{tabular}

Note: the city tier classification in this paper comes from the real estate market analysis of National Bureau of Statistics of the People's Republic of China.

\subsection{PVAR model}

Source: own study.

The PVAR model is a multivariate system equation that treats all variables as an endogenous system and examines the lags of all variables to reflect the interactions between them. The model can also process panel data with short time spans. The interaction between variables is analyzed by combining VAR models and panel data in time series through generalized moment estimation, impulse response function (IRF), and variance decomposition (FEVD). The general form of the model is as follows:

$$
y_{i t}=\alpha_{0}+\sum_{j=1}^{l} A_{j} y_{i t-j}+f_{j}+d_{t}+\varepsilon_{i t}
$$

Wherein $y_{i t}$ represents a vector consisting of the research variables of the $t$ research periods in the $i$ city, as housing price $(\mathrm{p})$ and rental price $(\mathrm{r})$ respectively. Explanatory variables are the lags of the variables, 1 is the lag coefficient, $\alpha_{0}$ is the intercept, $A_{j}$ is the matrix of the regression coefficient, $f_{j}$ and $d_{t}$ are fixed effect and time effect respectively, and $\varepsilon_{i t}$ is the random perturbation term.

\section{Empirical results}

\subsection{Average housing price and rent and its standard deviation}

After preliminary statistics, the research found that the average housing price of the sample data from June 2010 to December 2018 in 26 cities is 12809.14 yuan/m², with a maximum of 55150 and a minimum of 4472 . The average rent is 30.33 yuan $/ \mathrm{month} / \mathrm{m}^{2}$, with a maximum of 94.87 and a minimum of 11.86 .

Table 2

Variable statistical characteristics description

\begin{tabular}{cccccccc}
\hline & Variable & Obs. & Mean & Median & Std.Dev. & Min & Max \\
\hline \multirow{2}{*}{ 26 cities } & $\mathrm{p}$ & 2678 & 12809.14 & 9304.50 & 9294.10 & 4472.00 & 55150.00 \\
\cline { 2 - 8 } & $\mathrm{r}$ & 2678 & 30.33 & 26.00 & 13.06 & 11.86 & 94.87 \\
\hline \multirow{2}{*}{$\begin{array}{c}\text { First-tier } \\
\text { cities }\end{array}$} & $\mathrm{p}$ & 412 & 30316.42 & 27647.00 & 11573.12 & 12572.00 & 55150.00 \\
\cline { 2 - 8 } & $\mathrm{r}$ & 412 & 55.06 & 53.38 & 13.29 & 31.63 & 94.87 \\
\hline $\begin{array}{c}\text { Second- } \\
\text { tier cities }\end{array}$ & $\mathrm{p}$ & 2266 & 9625.99 & 8594.50 & 3449.54 & 4472.00 & 23961.00 \\
\cline { 2 - 8 } & $\mathrm{r}$ & 2266 & 25.83 & 24.83 & 6.17 & 11.86 & 56.37 \\
\hline
\end{tabular}

Source: own study.

In order to analyze whether the simultaneous rental and sales markets policy will affect the relationship between rent and housing prices in these cities, and whether the relationship between rental prices and housing prices in first-tier and second-tier cities is different before and after the simultaneous rental and sale markets policy, the analysis in this study will be based on the time node of July 2017. A new policy "Notice on Accelerating the Development of the Rental Housing Market in Large and Medium Cities with a Large Population inflow" was issued this month. This policy was jointly issued by many national ministries and commissions, including the Ministry of Housing and Urban-Rural Development of China, the National Development and Reform Commission, the Ministry of Public Security, the Ministry of Finance, the Ministry of Land and Resources, the People's Bank of China, the State Administration of Taxation, the State Administration of Industry and Commerce and the China Securities Regulatory Commission. All the national and local authorities 
attached great importance to it. The policy puts forward detailed requirements on how to cultivate the rental housing market, encourages local governments to increase the supply of new rental housing through various channels, such as building rental housing on new land and allocating rental housing in new commercial housing projects, supporting state-owned enterprises to play a leading and driving role in stabilizing rents, increasing the effective supply of rental housing, etc. In addition, it has elaborated supporting measures on financial policies and the implementation of "strengthening regulation and services" so as to better meet the diversified housing needs of residents. Local authorities and most of academics in China consider it the hallmark policy of simultaneous rental and sales markets.

Nowadays, the simultaneous rental and sale markets policy in China's housing market may have an impact on housing prices and rental prices. The housing market in different types of cities may also be characterized by different responses. This can also be seen in the figure below.
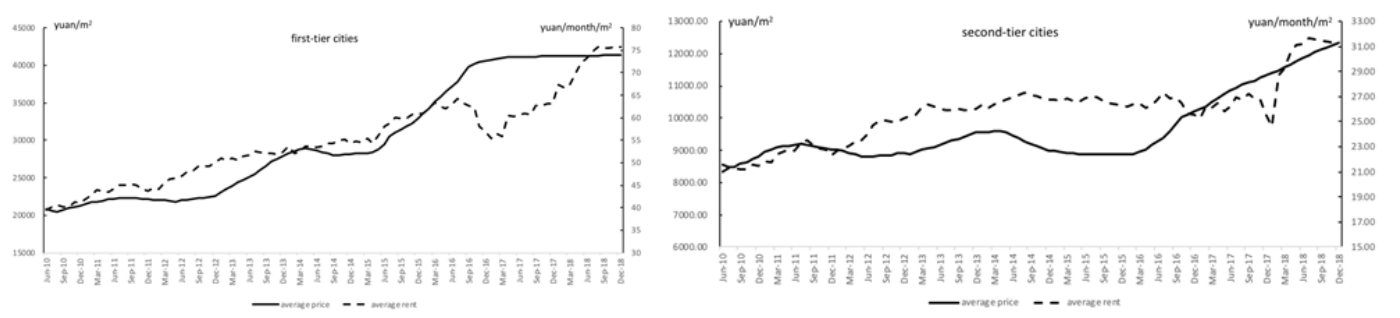

Fig. 2. Average housing price and rent in first-tier cities and second-tier cities of the sample.

Source: own study.

\subsection{Unit root Test}

Considering the conclusion from the preliminary statistics, the IPS test, the Fisher ADF test and the Fisher PP test are adopted. It can be seen from Table 3 that the original sequences of the variables in the samples are not stable. The first-order difference $d p$ and $d r$ of each variable is stable, including the samples of first-tier cities before the simultaneous rental and sale markets policy, the samples of firsttier cities after the simultaneous rental and sale markets policy, the samples of second-tier cities before simultaneous rental and sale markets policy and the samples of second-tier cities after simultaneous rental and sale markets policy. So, first-order single-integrated variables were uniformly adopted in the PVAR model of this study.

Table 3

Unit root Test

\begin{tabular}{|c|c|c|c|c|c|}
\hline & Test methods & $\mathbf{p}$ & $\mathbf{R}$ & $\mathrm{dp}$ & Dr \\
\hline \multirow{3}{*}{$\begin{array}{l}\text { First-tier cities before } \\
\text { simultaneous rental } \\
\text { and sale markets policy }\end{array}$} & IPS & 2.08 & -0.76 & $-6.89^{* * *}$ & $-14.96^{* * *}$ \\
\hline & Fisher ADF & 0.49 & 4.22 & $41.13^{* * *}$ & $156.39^{* * *}$ \\
\hline & Fisher PP & 0.04 & 4.53 & $63.99^{* * *}$ & $278.65^{* * \star}$ \\
\hline \multirow{3}{*}{$\begin{array}{l}\text { First-tier cities after } \\
\text { simultaneous rental } \\
\text { and sale markets policy }\end{array}$} & IPS & -0.20 & -0.72 & -0.60 & $-4.99^{* * * *}$ \\
\hline & Fisher ADF & 4.64 & 2.35 & $14.25^{* * *}$ & $32.18^{* * *}$ \\
\hline & Fisher PP & 3.76 & 2.14 & $51.90^{* * *}$ & $84.43^{* * *}$ \\
\hline \multirow{3}{*}{$\begin{array}{l}\text { Second-tier cities } \\
\text { before simultaneous } \\
\text { rental and sale markets } \\
\text { policy }\end{array}$} & IPS & 4.23 & $-2.65^{* *}$ & $-16.58^{* \star *}$ & $-31.80^{\text {t*k }}$ \\
\hline & Fisher ADF & 28.57 & $67.93^{* * *}$ & $298.65^{* \star *}$ & $896.75^{\text {kᄎk }}$ \\
\hline & Fisher PP & 14.63 & $81.86^{\text {*** }}$ & $616.86^{* * *}$ & $1706.77^{\star * *}$ \\
\hline \multirow{3}{*}{$\begin{array}{l}\text { Second-tier cities after } \\
\text { simultaneous rental } \\
\text { and sale markets policy }\end{array}$} & IPS & 3.15 & $-3.65^{* * *}$ & $-3.39^{* * *}$ & $-9.89^{* \star *}$ \\
\hline & Fisher ADF & 12.62 & 17.23 & $85.48^{* * *}$ & $119.24^{* * \star}$ \\
\hline & Fisher PP & 22.53 & 16.06 & $171.94^{* * \star}$ & $256.39^{* \star \star}$ \\
\hline
\end{tabular}

Note: $* * * * * *$ indicate significant levels of confidence at $1 \%, 5 \%$, and $10 \%$, respectively.

Source: own study. 


\subsection{Lag order selection}

According the model selection criteria and calculation results proposed by Andrews and Lu (2001), the first-order PVAR should be used in the analysis of the relationship between the rent and housing prices. Therefore, a PVAR model with a lag of 1 order is established according to Formula (1):

$$
Y_{i t}=B_{0}+B_{1} y_{i t-1}+F_{i}+D_{t}+U_{i t}
$$

\subsection{GMM estimation}

When the housing price is used as the dependent variable, the analysis shows that the housing price with the first-order lag poses a significant positive impact on current housing price regardless of the first-tier or second-tier cities before and after the simultaneous rental and sales markets policy. Before the simultaneous rental and sales markets policy in first-tier cities, the rental price with the first-order lag can inhibit the current housing price, and after the simultaneous rental and sales markets policy, the rental price with the first-order lag has a boosting effect on current housing price. Before the simultaneous rental and sales markets policy in the second-tier cities, the rental price with the firstorder lag also has a positive impact on the current housing price, though it is extremely insignificant; this positive impact, however, becomes significant and large after the simultaneous rental and sales markets policy. This shows that there is no significant correlation between rent and housing prices at the beginning, but later rent has a certain positive impact on the housing prices in all types of cities, and this boosting effect is more pronounced in second-tier cities compared with that in the first-tier cities.

When rent is used as a dependent variable, the analysis shows that the housing price with the first order lags has a weakly positive impact on rent before the simultaneous rental and sales markets policy in both the first-tier and second-tier cities. This suggests that the rental market is relatively more affected by the housing market. However, the negative impact of the rental price with the firstorder on current rental price has become significant in the first-tier cities after the simultaneous rental and sales markets policy. Before the simultaneous rental and sales markets policy in second-tier cities, the rental price with the first-order lag can significantly inhibit current rent; after the simultaneous rental and sales markets policy, however, such inhibition turns into weak promotion. The impact of housing prices with the first-order lag on rental price becomes insignificant in second-tier cities after rental and sales markets policy.

Table 4

GMM estimation results before and after the simultaneous rental and sales markets policy in first-tier and second-tier cities

\begin{tabular}{|c|c|c|c|c|}
\hline & \multicolumn{2}{|c|}{ First-tier city } & \multicolumn{2}{|c|}{ Second-tier city } \\
\hline & $\begin{array}{l}\text { Before simultaneous } \\
\text { rental and sales } \\
\text { markets policy }\end{array}$ & $\begin{array}{l}\text { After simultaneous } \\
\text { rental and sales } \\
\text { markets policy }\end{array}$ & $\begin{array}{l}\text { Before simultaneous } \\
\text { rental and sales } \\
\text { markets policy }\end{array}$ & $\begin{array}{l}\text { After simultaneous } \\
\text { rental and sales } \\
\text { markets policy }\end{array}$ \\
\hline Variable & & & & \\
\hline \multirow[t]{2}{*}{$\mathrm{dp}_{\mathrm{t}-1}$} & $0.66^{\star * *}$ & $0.54^{*}$ & $0.49^{* * *}$ & $0.45^{* * *}$ \\
\hline & $(0.00)$ & $(0.10)$ & $(0.00)$ & $(0.00)$ \\
\hline \multirow[t]{2}{*}{$\mathrm{dr}_{\mathrm{t}-1}$} & -17.40 & 4.12 & 0.67 & $9.06^{*}$ \\
\hline & $(0.69)$ & $(0.17)$ & $(0.92)$ & $(0.06)$ \\
\hline Variable & & & & \\
\hline \multirow[t]{2}{*}{$d p_{t-1}$} & 0.01 & 0.01 & $0.01^{* *}$ & 0.00 \\
\hline & $(0.16)$ & $(0.78)$ & $(0.02)$ & $(0.99)$ \\
\hline \multirow[t]{2}{*}{$\mathrm{dr}_{\mathrm{t}-1}$} & 0.10 & $-0.31^{*}$ & $-0.07^{* *}$ & 0.15 \\
\hline & $(0.40)$ & $(0.08)$ & $(0.02)$ & $(0.20)$ \\
\hline
\end{tabular}

Note: P-value is shown in parentheses. ${ }^{* * *},{ }^{* *},{ }^{*}$ indicate significant levels of confidence at $1 \%, 5 \%$, and $10 \%$, respectively.

Source: own study.

\subsection{Impulse response and variance decomposition}

Because the GMM estimation results are not enough to reveal the transmission mechanism between 
housing and rental prices, this paper performs an impulse response function (IRF) and variance decomposition (FEVD) estimation.

Fig. 3 is a graph of impulse response before and after the implementation of the simultaneous rental and sales markets policy in a first-tier city. Before the implementation of simultaneous rental and sales markets policy, both housing price and rental price had a positive impact in the later stage, but the positive impact of the two variables on their own future trends gradually became smaller until it approached zero. Housing prices can promote rent and the positive impact of housing prices on future rental price reached a maximum of 1.5 at the beginning, then gradually decreased to zero; the current rental price, on the other hand, had the strongest inhibitory impact on the first phase of future housing prices. After the implementation of simultaneous rental and sales markets policy, the rent posed a negative inhibitory effect on itself, and reached the greatest value in the first period, then heading towards zero. The positive effect of rent on future housing prices reaches a maximum of 9 in the first period and then heads towards zero; the impact of housing prices on future rental price has been shifted from inhibition to promotion, reaching a maximum of 2 in the first period and then gradually falling to zero.
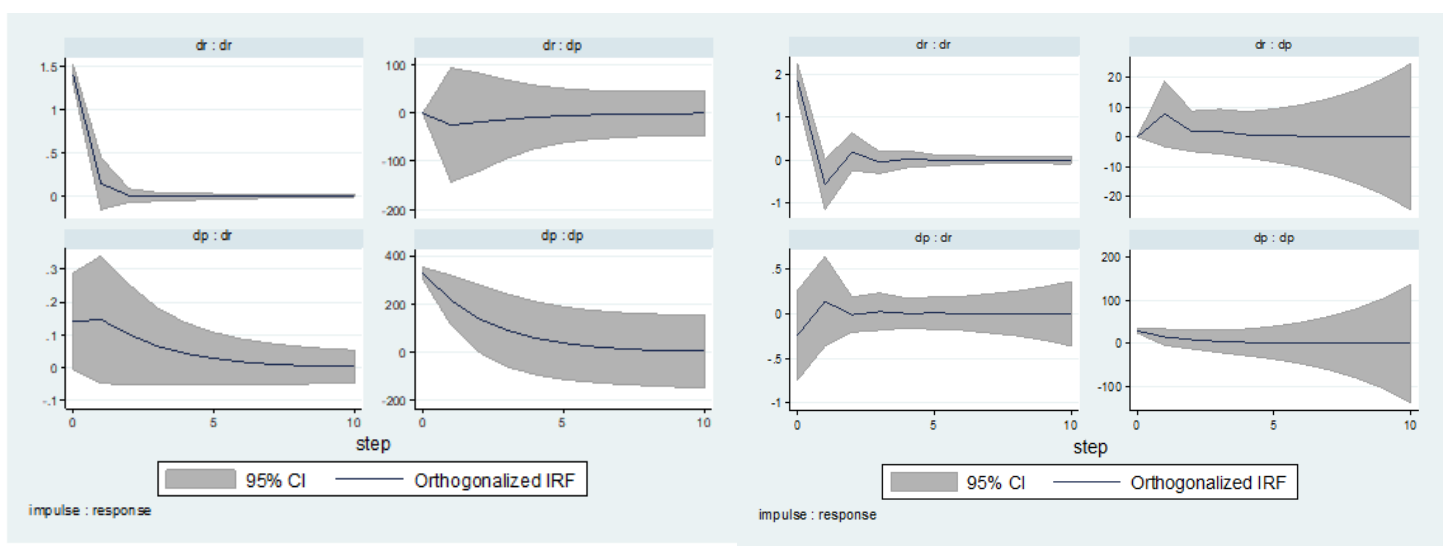

Fig. 3. Impulse response diagram before and after the simultaneous rental and sales markets policy in first-tier cities. Source: own study.

Fig. 4 shows that, before the simultaneous rental and sales markets policy in second-tier cities, the rental prices have a positive effect on their future values, reaching the greatest value in the first period, after which it tended towards zero. Housing prices have a positive effect on their future values, and this positive effect becomes smaller over time. Rental prices have little impact on future housing prices; housing prices have a positive effect on future rental prices in the first period and then rapidly converging to zero. After the implementation of the simultaneous rental and sales markets policy, both housing price and rental price have a positive effect on their own values. Moreover, as time goes by, this promotion becomes smaller and smaller, until it approaches zero. Rental prices have little impact on future housing prices, whereas housing prices have a positive effect on future rental Price, which then declines to zero.
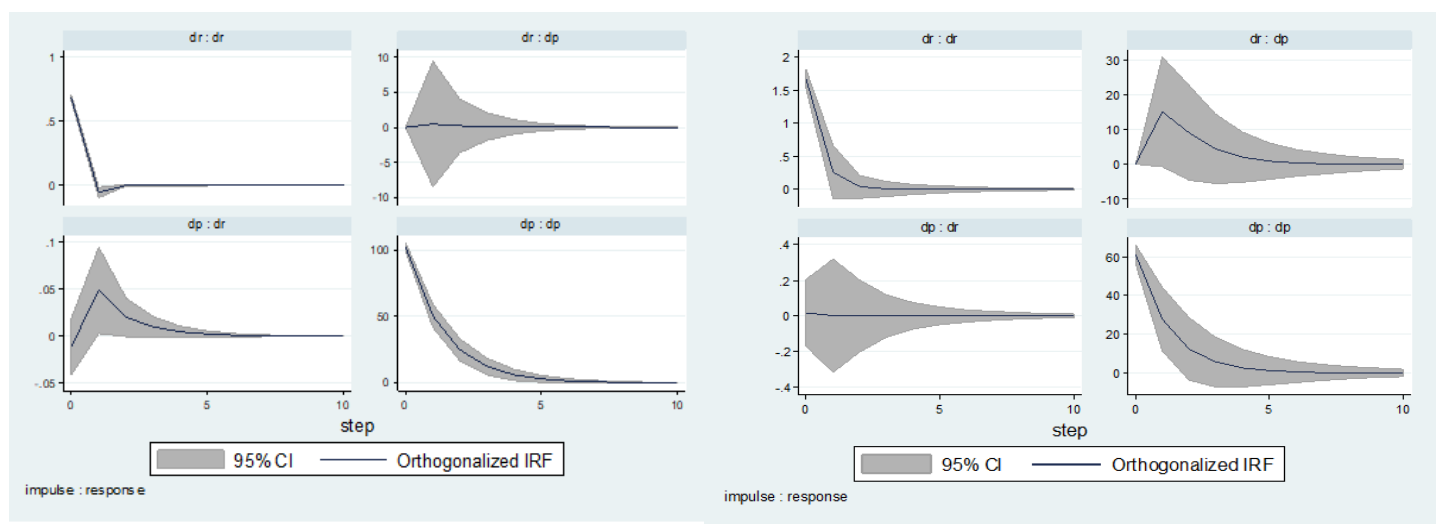

Fig. 4. Impulse response diagram before and after the simultaneous rental and sales markets policy in second-tier cities. Source: own study. 
In order to clearly measure the long-term mutual influence of the two variables, the composition of the variance contribution rate of the shock response to the fluctuation of each variable is further explained by the PVAR variance decomposition. Table 6 shows the variance decomposition results of each variable in the five forecast periods. Both the housing price and rental price have a major influence on their own values. However, this paper focoses more the interaction between the rental and sales markets.

Prior to the simultaneous rental and sales markets policy, $2.8 \%$ of variation of the housing price can be explained by rental price in the first-tier cities. After the simultaneous rental and sales markets policy, $2.0 \%$ of variation of housing price can be explained by rental price. In the second-tier cities, rental price explains approximately $0.7 \%$ of the variations in housing price before simultaneous rental and sales markets policy. By comparison, after the simultaneous rental and sales markets policy, the explanatory power of rental prices to housing price variation in first-tier cities is more powerful than that in second-tier cities.

Before the simultaneous rental and sales markets policy, $0.6 \%$ of variation of rental price can be explained by housing price in the first-tier cities. After the simultaneous rental and sales markets policy, $5.4 \%$ of variation of rental price can be explained by housing price. In the second-tier cities, housing price explains approximately $6.6 \%$ of the variations in rental price after simultaneous rental and sales markets policy. The explanatory power of housing prices to rental price variation in secondtier cities is greater than in first-tier cities.

Table 5

Variance decomposition

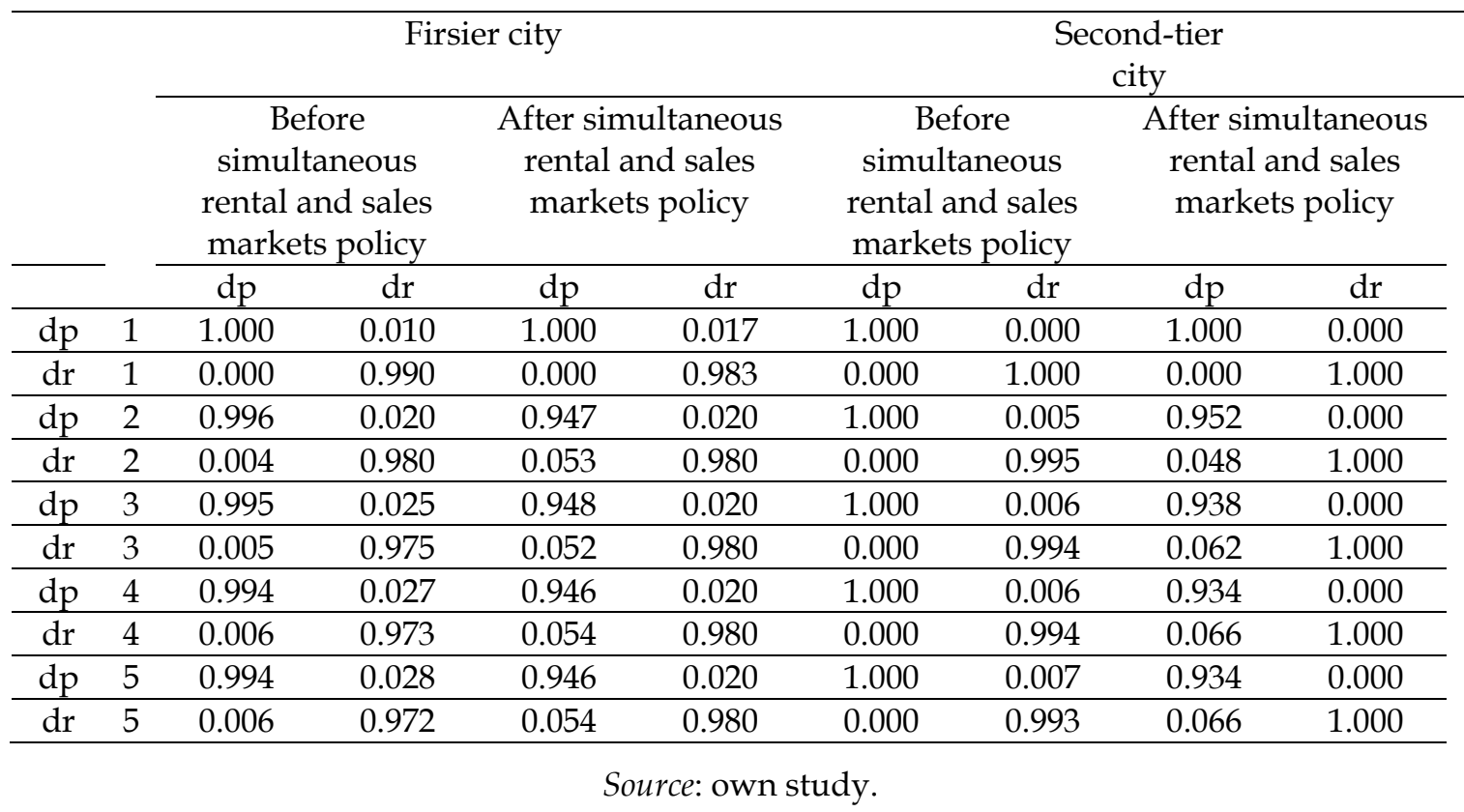

\section{Results and discussion}

Comprehensive comparative analysis shows that, after the implementation of the simultaneous rental and sales markets policy in the first-tier cities, the housing price with the first-order lag does not significantly enhance the current housing price, and the housing price is not greatly affected by the previous housing prices. The reason may be that, with the deepening of the purchase restriction policy, the housing prices in first-tier cities are gradually controlled, and dependence on the previous housing prices is gradually reduced. The positive impact of rental price with the first-order lag in firsttier cities on the housing prices has begun to increase since the simultaneous rental and sales markets policy was implemented. Combined with the significant negative impact of the rental price with firstorder lag on the current rental price, it can be seen that the simultaneous rental and sales markets policy has, to some extent, increased the substitution effect of rental prices on housing prices. When rental prices rise, consumers begin to shift their focus to the sales market, leading to the falling of new rental prices and the rise of housing prices. This indicates that the policy of simultaneous rental and sales markets has achieved certain effects, and gradually established a certain relationship between 
the rental and sales markets in the first-tier cities. The impact of housing prices with first-order lag in the first-tier cities on the rental price is no longer so obvious, which indirectly indicates that the rental market is relatively more affected by the sales market before the implementation of the simultaneous rental and sales policy. When the housing prices are controlled by the housing purchase restriction policy, the rental market is greatly affected by its own supply and demand so that the prosperity of the rental market also forms a benign interaction between the rental and sales markets.

For second-tier cities, before the policy of simultaneous rental and sales markets, housing prices with first-order lag had a positive impact on rent, and rent with first-order lag also posed a negative impact on the current rent, indicating that, in the rental and sales markets of asecond-tier city, the phenomenon of "sale emphasis and rent ignorance" still continues, and the impact of housing prices on rental price is relatively high. In the underdeveloped rental market of second-tier cities, consumers pay more attention to the property rights of owning houses. However, after the implementation of the simultaneous rental and sales markets policy, the impact of housing prices with first-order lag on rental price is no longer so significant, while the impact of the housing prices with first-order lag on the current housing prices is still obvious, and the effect of the rental price with first-order lag on the current rental price is not obvious enough. Compared with first-tier cities with large population inflows and large rental demand, the control policies may not be powerful enough in the second-tier cities, and housing prices can still be increased. Therefore, the impact of housing prices on themselves is relatively great. On the other hand, after the increase in the amount of rental housing available, the impact of housing prices on rental prices was weakened. Moreover, changes in housing prices also begin to be affected by changes in rental price and are no longer only affected by their own prices, which means that people in the second-tier cities begin to pay more attention to the future rent benefits of housing.

\section{Conclusions}

Housing prices and rents are affected by many factors, including supply and demand, and even policies. However, it should not be ignored that there is also an organic connection between the rental market and the sales market. In this paper, housing price and rent are regarded as two important factors which are interlinked in the housing market. The relationship between them changed after the Chinese government attached great importance to the policy of simultaneous rental and sales markets, but the effects of the policy are different in first-tier and second-tier cities.

All of these results indicate that the simultaneous rental and sales markets policy achieves a certain effect in both first-tier or second-tier cities. However, policy impact poses different effects due to the different context of housing sales and rental markets in China's cities. Therefore, local governments should take the characteristics of different cities into consideration and follow the laws of the markets when preparing a policy for simultaneous rental and sales markets. First-tier cities need to continue to strictly implement a purchase restriction policy, clamp down on property speculation and control the continuous rise of housing prices. In addition, it is important to increase the availabe land for longterm rental housing, improve the quality of rental housing, and meet the diversified housing demands of residents. Second-tier cities can take the opportunity to implement the policy of simultaneous rental and sales markets, standardize the rental market, and reduce the risk of a rapid rise in housing prices that first-tier cities have experienced. It must be noted that the irrational simultaneous growth of both the sales market and the rental market is to be avoided. Meanwhile, it is necessary to build an integrated risk monitoring system and make targeted regulations in the housing market for each city.

Funding: This work was supported by [Philosophy and Social Science Planning Project of Shanghai City] under Grant [number 2019BCK002]

\section{References}

Adams, Z., \& Füss, R. (2010). Macroeconomic determinants of international housing markets. Journal of Housing Economics, 19(1), 38-50. https:// doi.org/10.1016/j.jhe.2009.10.005

Apostolakis, G., \& Papadopoulos, A. P. (2019) Financial stability, monetary stability and growth: a PVAR analysis. Open Economies Review, 30(1), 157-178. https://doi.org/10.1007/s11079-018-9507-y

Campbell, S. D., Davis, M. A., Gallin, J., \& Martin, R. F. (2009). What moves housing markets: A variance decomposition of the rent-price ratio. Journal of Urban Economics, 66(2), 90-102. https://doi.org/10.1016/j.jue.2009.06.002 
Chen, C. F., \& Chiang, S. H. (2020). Time-varying causality in the price-rent relationship: Revisiting housing bubble symptoms. Journal of Housing and the Built Environment, 36(2), 1-20. https:// doi.org/10.1007/s10901-020-09781-1.

Clayton, J. (1996). Rational expectations, market fundamentals and housing price volatility. Real Estate Economics, 24(4), 441-470. https:// doi.org/10.1111/1540-6229.00699

Cui, N., Gu, H., Shen, T., \& Feng, C. (2018). The Impact of Micro-Level Influencing Factors on Home Value: A Housing Price-Rent Comparison. Sustainability, $10(12), 4343$. https:// doi.org/10.3390/su10124343

Czerniak, A., \& Rubaszek, M. (2018). The size of the rental market and housing market fluctuations. Open Economies Review, 29(2), 261-281. https://doi.org/10.1007/s11079-017-9452-1

DiPasquale, D., \& Wheaton, W. C. (1992). The cost of capital, tax reform, and the future of the rental housing market. Journal of Urban Economics, 31(3), 337-359. https://doi.org/10.1016/0094$\underline{1190(92) 90061-\mathrm{O}}$

Du, H.Y., \& Ma, Y.K. (2009). An Empirical Study of Granger Causality between the Housing Price and the Rent of Chinese Real Estate Market. Management Review, 21(1), 94-99.

Gallin, J. (2008). The long-run relationship between house prices and rents. Real Estate Economics, 36 (4), 635-658. https:// doi.org/10.1111/j.1540-6229.2008.00225.x

Jingkui, Z. (2005). Reconsideration on the Relationship between Real Estate Price, Land Price and Rent. Reform, (8), 23-27.

Kofner, S. (2014). The German housing system: fundamentally resilient? Journal of Housing and the Built Environment, 29(2), 255-275. https://doi.org/10.1007/s10901-013-9383-0

Li, N. (2014). Empirical study on the relation between house prices and rent on the basis of the real estate market's endogenous properties. Contemporary Economic Management, 36(3), 31-37.

Lisi, G. (2019). The search and matching process in the housing market. Journal of European Real Estate Research, 12(3), 392-404.

Magazzino, C. (2017). The relationship among economic growth, CO 2 emissions, and energy use in the APEC countries: A panel VAR approach. Environment Systems and Decisions, 37(3), 353-366.

Manganelli, B., Morano, P., \& Tajani, F. (2014). House prices and rents. The Italian experience. WSEAS Transactions on Business and Economics, 11(1), 219-226.

Meese, R., \& Wallace, N. (1994). Testing the present value relation for housing prices: Should I leave my house in San Francisco? Journal of urban Economics, 35 (3), 245-266.

Ouyang, Y., \& Li, P. (2018). On the nexus of financial development, economic growth, and energy consumption in China: New perspective from a GMM panel VAR approach. Energy Economics, (71), 238-252.

Potepan, M. J. (1996). Explaining intermetropolitan variation in housing prices, rents and land prices. Real Estate Economics, 24(2), 219-245. https://doi.org/10.1111/1540-6229.00688

Staikos, D., \& Xue, W. (2017). What drives housing prices, rent and new construction in China. International Journal of Housing Markets and Analysis, 10(5), 662-686. https://doi.org/10.1108/IJHMA-12-2016-0080

Tomal, M. (2020). Modelling housing rents using spatial autoregressive geographically weighted regression. A case study in Cracow, Poland. International Journal of Geo-Information 9(6), 346. https://doi.org/10.3390/ijgi9060346.

$\mathrm{Tu}$, Q., Haan, J., \& Boelhouwer, P. (2016). The mismatch between conventional house price modeling and regulated markets: insights from The Netherlands. Journal of Housing and the Built Environment, 32(3), 599-619.

Wu, Y., \& Tidwell, A. (2015). Inflation-hedging properties of regional Chinese real estate market: evidence from 35 cities in China. Applied Economics, 47(60), 6580-6598. https://doi.org/10.1080/00036846.2015.1080811

Zhai, D., Shang, Y., Wen, H., \& Ye, J. (2018). Housing Price, Housing Rent, and Rent-Price Ratio: Evidence from 30 Cities in China. Journal of Urban Planning and Development, 144(1), 04017026.

Zhang, H., Li, L., Hui, E. C.-M., \& Li, V. (2016). Comparisons of the relations between housing prices and the macroeconomy in China's first-, second-and third-tier cities. Habitat International, (57), 2442.

Zhang, S.D., Zhao, H.P., \& Li, B. (2014). The relationship between real estate price and rent under the effect of macro-control: Empirical evidence from thirty-five large and medium scale cities of China. Journal of Applied Statistics and Management, 13(2), 305-316. 